\title{
Note on Citations
}

F ull bibliographic citations are supplied on the first instance in each chapter; subsequent references generally use only the author's last name and an abbreviated title. Citations of archival material vary according to the standards requested by each archive. I have, however, included more information than required for citations from acts contained in the Zentrales Staatsarchiv in Merseburg because these documents are so central to my arguments.

Schulprogramme often present cataloging problems to libraries in the United States and Germany; they also present citation problems for scholars who use more than a few. Their official titles are lengthy, cumbersome, and inconsistent. Because major depositories arrange them alphabetically by city, and within each city by school and year, I have used only this information in citing them. (This system is similar to the way a university Vorlesungsverzeichniss or Chronik is customarily cited.) Most of the Schulprogramme I have used are found in the Staatsbibliothek Preußischer Kulturbesitz in Berlin and the Universitätsbibliothek in Giessen. 